\title{
Hubungan antara Infeksi Cacing Usus dan Tuberkulosis
}

\author{
Yuliana \\ Staf Pengajar Bagian Parasitologi Fakultas Kedokteran Universitas Trisakti \\ Alamat Korespondensi : y_ln28@yahoo.com
}

\begin{abstract}
Abstrak
Cacing usus masih sering diabaikan meskipun prevalensi kecacingan tinggi. Hal ini dikarenakan kurangnya edukasi mengenai beratnya konsekuensi infeksi cacing ini. Begitu juga dengan Mycobacterium tuberculosis (Mtb). Distribusi geografik kedua penyakit ini saling tumpang tindih, sehingga koinfeksi sering terjadi. Respons imun tubuh terhadap dua penyakit ini ternyata saling bertolak belakang. Infeksi cacing usus merangsang respons imun Th2 dan Treg. Kedua respons ini akan menekan imunitas Th1, yang diperlukan sebagai kontrol dari infeksi Mtb. Kondisi ini membuat kedua penyakit ini bisa menginfeksi satu individu di waktu yang bersamaan. Hal ini membuat penduduk di daerah endemis lebih rentan terhadap kedua penyakit ini. Dalam artikel ini, penulis mencoba membahas kedua penyakit ini dan respons tubuh terhadap mereka.
\end{abstract}

Kata kunci : infeksi cacing usus, tuberkulosis, respon imun

\section{Correlation between Helminth Infection and Tuberculosis}

\begin{abstract}
Intestinal worms often do not receive adequate attention despite high prevalence of infestation. This is due to the lack of education regarding the severe consequences of helminth infection. Similarly, Mycobacterium tuberculosis (MTB), is also highly prevalent. The geographic distribution of these two diseases overlaps, making co-infection possible to happen. The immune responses to these two diseases are contradictory. Helminth imfection stimulates Th2 dan Treg immune response. These two immune responses suppress Th1 immune response, which is required to control MTB infection. Therefore, it is possible for these two diseases to infect one individual simultaneously. People in endemic areas are susceptible to these two diseases. This article discusses both diseases and the immune responses against them.
\end{abstract}

Keywords: helminth infection, tuberculosis, immune response

\section{Pendahuluan}

Cacing usus telah menginfestasi seperempat jumlah populasi dunia, ${ }^{1}$ namun masih sering diabaikan. Hal ini dikarenakan kurangnya edukasi mengenai beratnya konsekuensi infeksi cacing ini. Begitu juga Mycobacterium tuberculosis (Mtb), diperkirakan menginfeksi sekitar sepertiga dari populasi dunia. ${ }^{2}$ Distribusi geografik kedua penyakit ini saling tumpang tindih sehingga membuat koinfeksi antara kedua patogen tersebut sering terjadi. ${ }^{3}$ Berat ringannya infeksi tergantung pada imunitas orang yang terinfeksi dan berapa banyak cacing yang masuk ke dalam tubuh penderita.

Kebalikan dari infeksi yang disebabkan oleh bakteri, virus, protozoa, dan pathogen jamur, infeksi kronis cacing usus diasosiasikan dengan respons imun Th2 yang dikarakteristik oleh eosinofilia, peningkatan kadar IgE dan produksi dari sitokin tipe 2 seperti IL-4, IL-5, dan IL-13. ${ }^{2,3}$ Seiring dengan berjalannya waktu, infeksi kronis cacing menyebabkan terjadinya proses imunoregulator melalui pengaturan sel $\mathrm{T}$ (Treg), makrofag yang juga 
teraktivasi dan sitokin inhibitor IL-10 dan TGF $\beta .^{2,3}$ Efek imun ini pada pejamu sangat kompleks. $^{2,3}$

Proses regulasi imun yang disebabkan oleh infeksi cacing akan meningkatkan kemungkinan hidup parasit pada tubuh pejamu, juga akan memengaruhi respons imun terhadap antigen lain. ${ }^{3}$ Keuntungan yang didapat pejamu dari regulasi imun ini adalah terlindunginya pejamu dari proses alergi dan penyakit autoimun. ${ }^{3}$ Namun negatifnya, infeksi cacing usus bisa menghambat perkembangan respons imun yang adekuat pada beberapa vaksin seperti BCG, tetanus, dan kolera. ${ }^{3}$

Sementara infeksi Mycobacterium tuberculosis membutuhkan interferon gamma (IFNr) yang diatur oleh respons imun Th1, infeksi cacing memicu respons imun Th2 dan respons pengaturan imun, yang kerjanya menghambat reaksi imun $\mathrm{Th} 1 .^{3}$ karena itu muncul hipotesis bahwa infeksi cacing usus dapat mengganggu perkembangan respons imun tubuh terhadap Mtb. Tetapi pengaruh klinis infeksi cacing usus kronis pada koinfeksi dengan organisme lain seperti Mycobacterium tuberculosis, plasmodium, atau HIV masih kontroversial dan belum sepenuhnya dipahami. ${ }^{3}$

\section{Epidemiologi}

Diperkirakan tuberkulosis (TB) telah menginfeksi sepertiga dari populasi dunia, dan menyebabkan dua juta kematian setiap tahunnya. $^{3,4}$ Kebanyakan kasus $\mathrm{TB}$ ada di negara-negara berkembang yang merupakan daerah endemis $\mathrm{TB}^{2-4} \mathrm{~TB}$ banyak terjadi di Rusia, India, Asia Tenggara, Afrika Subsahara, dan sebagian Amerika Latin. ${ }^{4,5}$ World Health Organization (WHO) memerkirakan pada tahun 2010 ada 8,8 juta kasus TB baru di dunia. Kebanyakan muncul di Asia (59\%) dan Afrika (26\%). ${ }^{4,5}$

Infeksi cacing usus merupakan salah satu infeksi paling sering di dunia, terutama di negara berkembang yang memiliki iklim tropis atau subtropis. ${ }^{1}$ Ketersediaan air bersih yang sangat terbatas dan kurangnya fasilitas sanitasi merupakan beberapa alasan tingginya insidens infeksi cacing usus di negara-negara ini. ${ }^{1}$

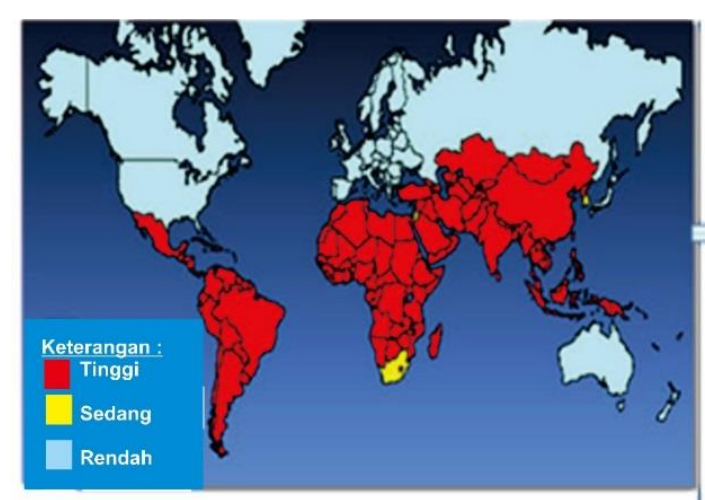

Gambar 1. Daerah Distribusi Insiden Infeksi Cacing Usus ${ }^{6}$

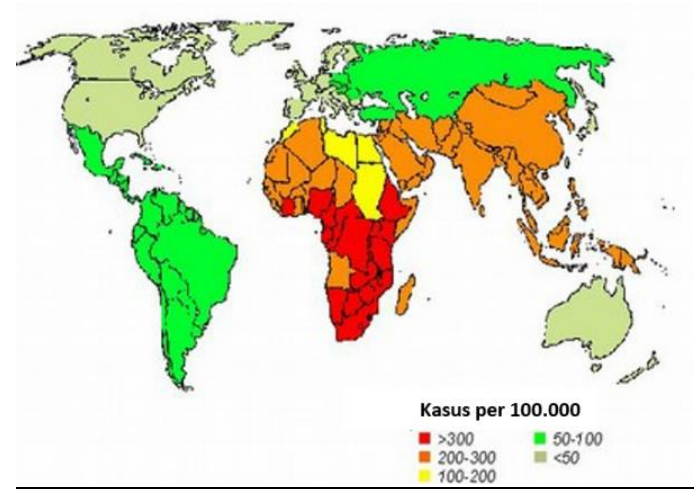

Gambar 2. Daerah Distribusi Insiden Mycobacterium tuberculosis 5

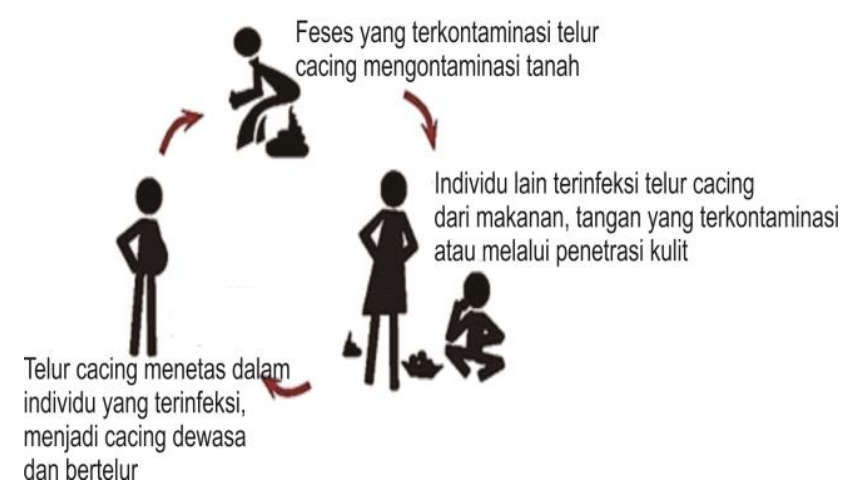

Gambar 3. Siklus Infeksi Cacing Usus ${ }^{7}$

\section{Siklus Hidup}

Cacing usus ditransmisikan melalui sel telur yang dikeluarkan melalui tinja, yang kemudian akan mengontaminasi tanah. ${ }^{1,7,8}$ Spesies utama yang banyak menginfeksi manusia adalah Ascaris lumbricoides, Trichuris trichiura, Necator americanus, dan Ancylostoma duodenale. 1,7,8 $^{\text {us }}$

Infeksi cacing usus dimulai ketika menelan telur cacing, atau ketika larva cacing menembus kulit. Telur cacing biasanya keluar 
bersama tinja penderita kemudian bisa menginfeksi orang lain melalui tangan penderita yang kurang bersih setelah buang air dan makanan atau minuman yang terkontaminasi telur cacing tersebut. Setelah tertelan, telur akan menetas dan berkembang menjadi cacing dewasa dan siap kawin dan bertelur kembali di usus orang yang terinfeksi. Pada saat itulah biasanya infeksi ini memberikan gejala klinis pada penderitanya. Infeksi cacing usus memberikan gejala klinis yang cukup luas yaitu diare, sakit perut, malaise, dan lemas. Cacing tambang bahkan bisa menyebabkan kehilangan darah akibat perdarahan di usus yang kemudian menyebabkan anemia. ${ }^{7,8}$

Sementara pada tuberkulosis, infeksi primer dimulai pada saat menginhalasi Mtb dan diakhiri dengan respon imun yang dimediasi oleh Tsel, yang akan mengontrol infeksi pada 95\% kasus. Setelah masuk ke dalam tubuh manusia, Mtb akan diikat dan dibunuh oleh makrofag alveolar. Tetapi jika Mtb bertahan hidup maka dia akan terus bertambah banyak, melisiskan sel pejamu, menginfeksi lebih banyak makrofag dan melalui makrofag ini Mtb bisa mencapai kelenjar limfe., ${ }^{2,9}$ Makrofag terinfeksi Mtb berinteraksi dengan kedua $\mathrm{CD}^{+}$dan $\mathrm{CD} 8^{+}$. Sel $\mathrm{T}$ kemudian akan menginduksi pelepasan sitokin, yang mengarah aktivasi makrofag yang akan berperan mengontrol infeksi Mtb. ${ }^{9}$

\section{Sistem Imunologis}

Pada infeksi cacing usus, larva stadium tiga akan masuk ke dalam lapisan submucosa duodenum. Setelah menjadi dewasa, cacing kembali masuk ke dalam lumen duodenum. Infeksi primer dapat diobati dengan antihelmintik. Infeksi sekunder dapat di atasi oleh sistem pertahanan tubuh pejamu, yaitu dengan respon imun Th2. ${ }^{10}$
Antigen cacing usus akan berikatan dengan sel CD4 dan menyebabkan aktifnya respon imun $\mathrm{TH} 2$. Sel TH2 akan mengeluarkan sitokinsitokin, yaitu interleukin-4 (IL-4), IL-3, IL-9, dan IL-5. Selain itu sel TH2 juga akan mendorong terbentuknya IgE. IL-4 dan IL-13 akan menyebabkan stress pada cacing dan memicu perubahan fisiologis usus (peningkatan kontraksi usus dan kecepatan alir) yang pada akhirnya akan mengeluarkan cacing dari tubuh pejamu. ${ }^{10}$ Tuberkulosis disebarkan melalui udara dan dapat menimbulkan infeksi dengan ataupun tanpa lesi primer yang dapat dilihat. Lesi seperti itu dapat terjadi di bagian paru mana saja, tetapi karena alasan aerodinamik, lebih banyak terjadi di basal paru dan bagian yang lebih dekat dengan pleura. Respons Th1 akan berkembang secara cepat setelah Mtb masuk ke dalam tubuh. Pada 90-95\% individu, infeksinya bersifat laten, yang kemungkinan terefleksi oleh DNA Mtb yang dapat dideteksi menggunakan PCR in situ (terlihat sebagai materi intrasitoplasmik biru) dalam jaringan dengan sedikit infiltrat seluler. Pada sebagian kecil individu, dapat terjadi perkembangan penyakit progresif, paling sering di puncak paru-paru, di mana dalam rasio ventilasi perfusi darah tertinggi. Namun, dalam kebanyakan orang yang terinfeksi, penyakit ini akan tetap laten selama beberapa dekade, meskipun dapat diaktifkan kembali ketika seorang individu mengalami imunosupresi, khususnya melalui infeksi HIV. Tuberkulosis progresif ditandai dengan penurunan berat badan, faktor toksisitas dari tumor nekrosis, kavitasi, dan fibrosis paru, meskipun interferon gamma yang diproduksi oleh sel Th1 dapat mengurangi jumlah fibrosis. Rongga akhirnya terbuka ke bronkus, yang memungkinkan penyebaran TB oleh aerosol selama batuk. ${ }^{11}$ 


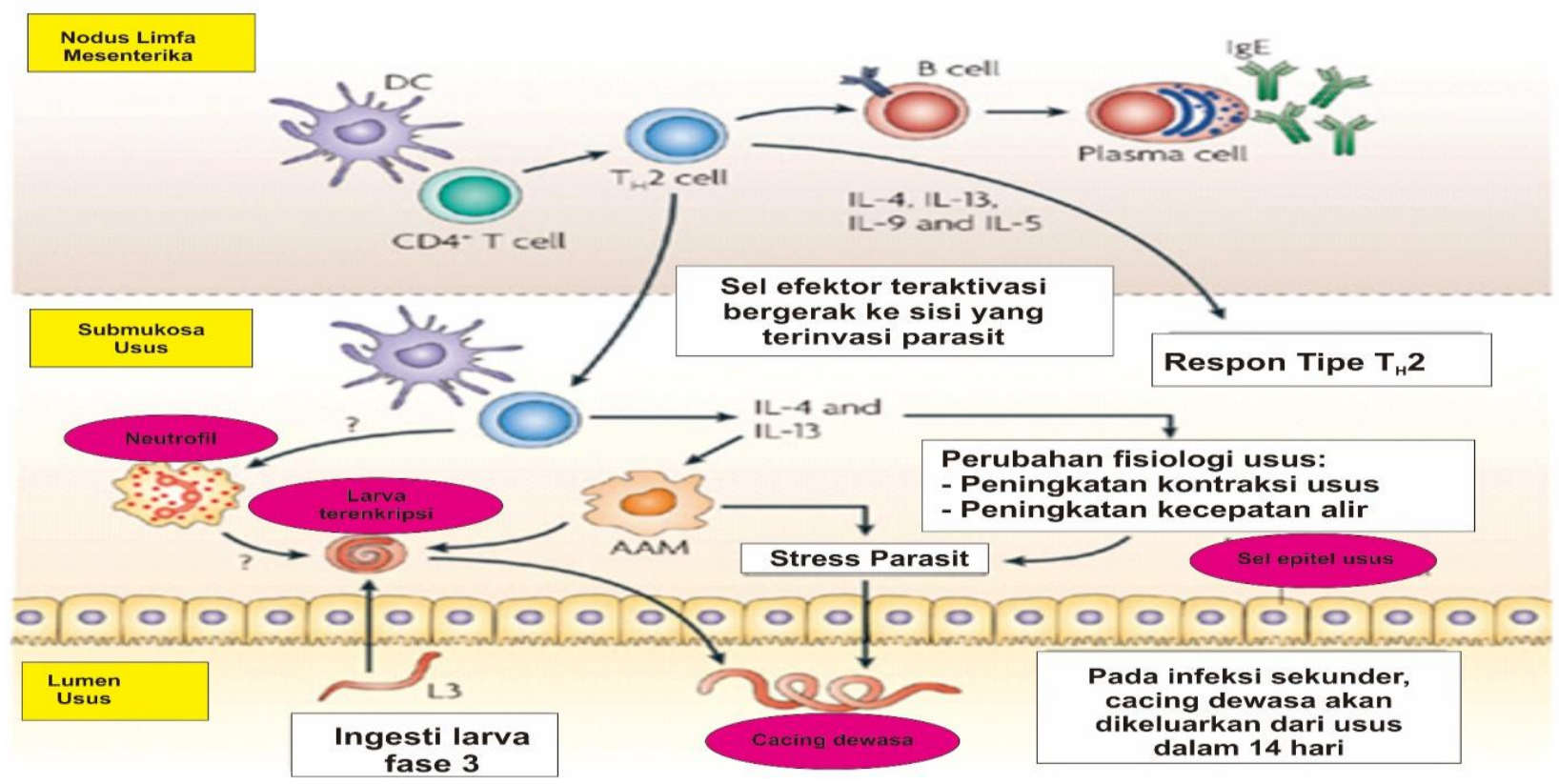

Gambar 4. Proses Imunologis yang Terjadi pada Infeksi Cacing ${ }^{10}$

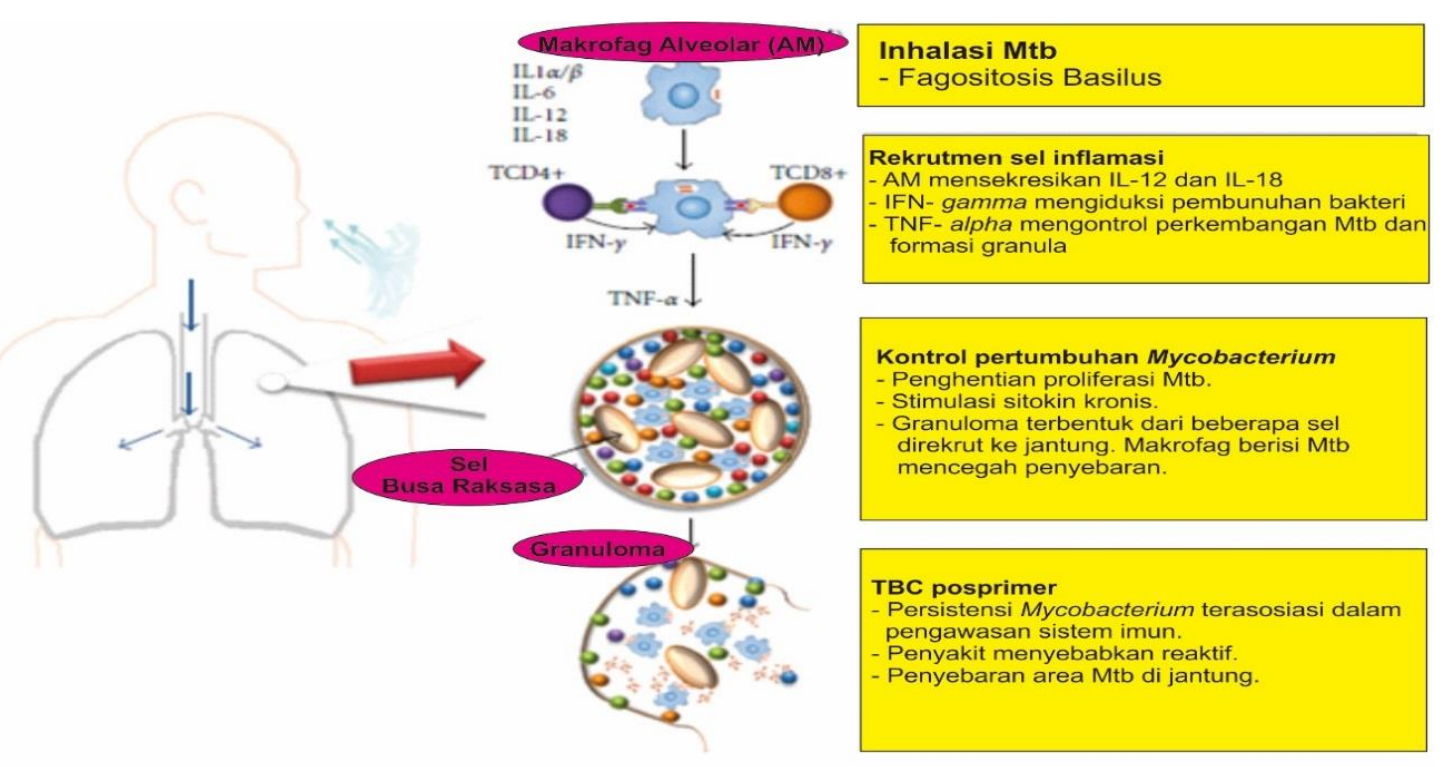

Gambar 5. Proses Imunologis yang Terjadi pada Tuberkulosis 
Proses patologis tuberkulosis akan terjadi dalam empat tahap. Yang pertama inhalasi dari Mtb diikuti dengan interaksinya dengan makrofag melalui reseptor selular. Mekanisme fagositosis makrofag kemudian diaktifkan. Tahap kedua adalah proses perekrutan sel peradangan, yaitu ketika Mtb yangberproliferasi di dalam makrofag menyebabkan produksi sitokin pro-inflamasi. Lingkungan lokal inflamasi menginduksi perekrutan beberapa tipe sel termasuk monosit, neutrofil, dan sel dendritik ke tempat infeksi. Tingginya kadar TNF- $\alpha$ berkontribusi untuk mengendalikan pertumbuhan Mtb dengan pembentukan granuloma. Tahap ketiga adalah pengendalian proliferasi mycobacterium melalui kedatangan sel imun ke tempat infeksi, termasuk sel $\mathrm{T}$, sehingga terorganisasi dalam struktur yang disebut granuloma. Granuloma akan secara efisien menghentikan proses proliferasi sekaligus memerangkap mycobacterium sehingga mencegah penyebarannya. Tahap keempat yaitu tuberkulosis post primer atau infeksi mycobacterium persisten terkait dengan kegagalan sistem pengaturan imun yang akan meningkatkan risiko penyakit laten menjadi aktif kembali, dimana terjadi kerusakan organorgan dekat bronkus dan penyebaran Mtb ke area lain dari paru-paru dan penularan penyakit ke orang lain. ${ }^{11}$

\section{Infeksi Cacing Usus dan Tuberkulosis}

Seperti yang telah dibahas sebelumnya, infeksi cacing usus merangsang respons imun Th2 dan Treg. Kedua respons ini akan menekan imunitas Th1, yang diperlukan sebagai kontrol dari infeksi Mtb. Respons imun Th1 dan Th2 saling memberi pengaruh negatif satu sama lain, baik secara in vitro maupun in vivo: interferon gamma (IFN- $\gamma$ ) akan menghambat respons Th2 sementara IL-4 menghambat respons tipe Th1. ${ }^{1}$

Hal ini menjadi semakin jelas bahwa infeksi cacing, selain respons $\mathrm{Th} 2$, bisa juga menginduksi populasi sel $\mathrm{T}$ penekan dikenal sebagai peraturan Sel $\mathrm{T}$ (Treg). Treg menghasilkan sitokin penghambatan (IL-10 dan TGF-b) yang menekan respon Th1 dan mengganggu aktivasi sel $\mathrm{T}$ efektor. Awalnya diduga bahwa Treg memiliki peranan penting dalam kontrol sel $\mathrm{T}$ patogenik dan respons autoimun. ${ }^{2,3}$ Belakangan ditemukan bahwa
Treg bisa diinduksi untuk mengatur respons terhadap patogen. Treg terlibat pada reaksi imunosupresi yang diinduksi oleh cacing. ${ }^{2,3}$

Pada percobaan infeksi nematoda, telah diamati bahwa ada peningkatan fungsi Treg yang terkait dengan respons Th2 yang telah diatur. ${ }^{2,3}$ Fungsi Treg yang meningkat akibat infeksi cacing dapat menekan respons Th1 yang ditujukan terhadap antigen dan /atau patogen. Namun, dampak dari Th2 yang diinduksi oleh cacing dan /atau respons Treg sebagai perlindungan terhadap penyakit mikobakteri atau vaksinasi terhadap patogen intraseluler pada umumnya masih harus diselidiki. Ini adalah pertanyaan-pertanyaan yang menjadi perhatian penting khususnya di negara berkembang, dimana kedua infeksi yang umum., ${ }^{2,3}$

Sebuah penelitian di Afrika Selatan menemukan kejadian tuberkulosis tertinggi di desa-desa termiskin. Alasan untuk konsentrasi tuberkulosis yang tinggi di desa-desa ini tidak dapat hanya semata-mata dikaitkan dengan kepadatan penduduk atau kecepatan transmisi Mtb tetapi ada juga faktor dominan galur unik Mtb, yang menunjukkan adanya reaktivasi infeksi laten. Komunitas miskin di desa-desa tersebut juga ternyata terinfeksi dengan infeksi cacing usus yang menginduksi respon imun Th2 yang poten untuk kedua antigen parasit dan nonparasit. Ada hipotesis bahwa infeksi cacing usus dapat meningkatkan kerentanan terhadap infeksi tuberkulosis. Hipotesis ini kemudian didukung oleh temuan bahwa respons seluler tuberkulosis spesifik dikurangi oleh insiden infeksi cacing usus pada manusia. ${ }^{1}$

\section{Penutup}

Infeksi cacing usus dan tuberkulosis merupakan dua penyakit yang sering terjadi di berbagai belahan dunia, khususnya di negaranegara berkembang. Adanya kesamaan wilayah tempat ini sering mengakibatkan koinfeksi antara kedua penyakit ini. Dari berbagai penelitian ditemukan bahwa infeksi cacing usus akan merangsang respons imun Th2 dan Treg yang akan menekan respons imun Th1. Padahal untuk pertahanan terhadap Mtb diperlukan respons imun Th1. Sehingga disimpulkan kemudian bahwa infeksi cacing merupakan salah satu faktor yang menentukan perkembangan infeksi TB. Temuan ini dapat 
berimplikasi penting untuk kontrol infeksi tuberkulosis di daerah endemik infeksi cacing usus di dunia.

\section{Daftar Pustaka}

1. Jourdan PM, Lamberton PHL, Fenwick A, Addiss DG. Soil-transmitted helminth infection. The lancet 2018; 391 issue 10117, 252-65.

2. Babu S, Nutman TB. Helminthtuberculosis co-infection: an immunologic perspective. Trends Immunol 2016 Sept; 37(9): 597-607.

3. $\mathrm{Hu}^{\prime \prime}$ bner MP, Killoran KE, Rajnik M, Wilson S, Yim KC, et all. Chronic helminth infection does not exacerbate mycobacterium tuberculosis infection. PLOS Neglected tropical diseases 2012; vol 6 issue 12 1-9.

4. Li XX, Zhou XN. Co-infection of tuberculosis and parasitic diseases in humans: a systematic review. Parasites and Vectors 2013;6: 79.

5. Jackson JC, Roesel D. Epidemiology of TB: primary care tools for the management of TB [internet]. Ethnomed. [cited 21 Agustus 2018]. Available from http://ethnomed.org/clinical/tuberculosis/f irland/epidemiology-of-tb .

6. Strosberg SA. (2014) The humanhookworm assemblage: contingency and the practice of helminthic therapy [internet]. UKnowledge. [cited 21 Agustus 2018]. Available from http://uknowledge.uky.edu/cgi/viewconte nt.cgi?article $=1028 \&$ context $=$ geography_ etds $\backslash$
7. What are intestinal worms (soil transmitted helminthiasis)? [internet]. WHO. [cited 22 Agustus 2018]. Available from

http://www.who.int/intestinal_worms/dise ase/en/ .

8. Hedley L, Wani RLS. Helminth infections: diagnosis and treatment. The Pharmaceutical Journal 2015; vol 295 no7882.

9. Fogel N. Tuberculosis: a disease without boundaries. Tuberculosis 2015; 95: 52731.

10. Anthony RM, Rutitzky LI, Urban JF, Stadecker MJ, Gause WC. Protective immune mechanisms in helminth infection. Nature Reviews Immunology 2007; 7975-87.

11. Zuñiga J, García DT, Mendoza TS, Reyna TSR, Granados J, Yunis EJ. Cellular and humoral mechanisms involved in the control of tuberculosis. Clinical and DevelopmentalImmunology 2012; article id 193923 1-18.

12. Borkow G, Leng Q, Weisman Z, Stein M, Galai N, Kalinkovich A, Bentwich Z. Chronic immune activation associated with internal helminth infections results in impaired signal transduction and anergy. The journal of Clinical Investigation 2000; 106 (8).

13. Elias D, Mengistu G, Akuff H, Britton S. Are intestinal helminthes risk factors for developing active tuberculosis?. Tropical Medicine and International Health. 2006; 11(4):551- 